Article

\title{
Eucalyptus globulus Coppices in Portugal: Influence of Site and Percentage of Residues Collected for Energy
}

\author{
Isabel Malico ${ }^{1,2, *(1)}$ and Ana Cristina Gonçalves ${ }^{3}$ \\ 1 Departamento de Engenharia Mecatrónica, Escola de Ciências e Tecnologia, Universidade de Évora, \\ Rua Romão Ramalho 59, 7000-671 Évora, Portugal \\ 2 LAETA, IDMEC, Instituto Superior Técnico, Universidade de Lisboa, Av. Rovisco Pais 1, \\ 1049-001 Lisboa, Portugal \\ 3 Departamento de Engenharia Rural, Escola de Ciências e Tecnologia, Instituto Mediterrânico de Agricultura, \\ Ambiente e Desenvolvimento (MED), Instituto de Investigação e Formação Avançada, Universidade de Évora, \\ Apartado 94, 7002-544 Évora, Portugal; acag@uevora.pt \\ * Correspondence: imbm@uevora.pt; Tel.: +351-266-745-372
}

Citation: Malico, I.; Gonçalves, A.C. Eucalyptus globulus Coppices in Portugal: Influence of Site and Percentage of Residues Collected for Energy. Sustainability 2021, 13, 5775. https://doi.org/10.3390/su13115775

\section{Academic Editors:}

Mohammad Valipour and

Marc A. Rosen

Received: 12 April 2021

Accepted: 18 May 2021

Published: 21 May 2021

Publisher's Note: MDPI stays neutral with regard to jurisdictional claims in published maps and institutional affiliations.

Copyright: (c) 2021 by the authors. Licensee MDPI, Basel, Switzerland. This article is an open access article distributed under the terms and conditions of the Creative Commons Attribution (CC BY) license (https:/ / creativecommons.org/licenses/by/ $4.0 /)$.

\begin{abstract}
Studies that quantify forest bioenergy potentials hardly address the questions of site quality, proportion and type of residues removed from the stands, and environmental impacts of those removals. However, those factors are important for energy-potential results and forest sustainability. This study compares, in terms of residual biomass availability for energy production and of sustainability, different locations, site indices, and forest management strategies in Eucalyptus globulus stands for pulp and paper in northern and central Portugal. A growth and production simulator was used to calculate the availability of residues and the area needed to supply a biomass-fired power plant under a variety of scenarios. Regions with more rainfall generate more residues, but site index and quantity and type of residues harvested are the most important factors. Under the different scenarios analyzed, the amount of residues potentially harvested range from 0.7 to $4.3 \mathrm{Mg} \mathrm{ha}^{-1} \mathrm{a}^{-1}$, the upper bound corresponding to a scenario where stumps are valorized. The maximization of residue removal maximizes the bioenergy produced but has to be considered prudently. Studies indicate that stump removal has limited effect on Eucalyptus globulus stand productivity, diversity, and system sustainability, but impacts of residue removals increase with a decrease in site index.
\end{abstract}

Keywords: bioenergy; biopower; energy potential; growth and production simulator; silviculture; site index; environmental impacts

\section{Introduction}

Eucalyptus globulus is an abundant tree in mainland Portugal, one of the countries in the world with the largest planted area of this species [1]. According to the latest Forest National Inventory [2], Eucalyptus globulus represents 26.2\% of the Portuguese forest area, covering 845,000 ha of which 73\% (616.3 thousand hectares) is located in the north and center of the country [2]. In Portugal, this forest tree is almost exclusively planted for pulp and paper production [3] and, in smaller amounts, for the wood panel industry [4]. These industrial sectors are capable of using relatively small diameters [4], which generates less amount of residues per tree. However, as the stands have high densities, the amount of residues per unit area are considerable. The remains of the harvest (e.g., tree tops, branches, and stumps) can be used for energy purposes.

The proportion of biomass residues that result from forestry operations is frequently estimated as a percentage of the above-ground biomass. Its value depends on the species and stand structure and ranges from $0 \%$ to $80 \%$ [5]. The mostly used ratio is between $13 \%$ and $17 \%$, usually $15 \%$ [6,7]. In some publications, the proportion of biomass residues is expressed in residue production yields, generally having units of tons of residues per year and area (e.g., $[8,9])$. 
The residues obtained from forest management practices in Portugal are already valorized to some extent. In 2019, most (53\%) of the energy from firewood, forest and plant residues, pellets, and other agglomerates was consumed in the residential sector [10], which mainly uses biomass for heating [11]. The choice for the source of wood in households is much dependent on the composition of the local forest, and the Eucalyptus globulus is important in the regions were the species is abundant. Despite its importance, the share of the residential sector has been decreasing. This was particularly noteworthy from 2018 to 2019, when the consumption of energy from this type of biomass in dedicated biomass power plants and industry increased around $20 \%$, while it remained practically constant in the residential sector. Also striking is the role of the pulp and paper industry, which represented more than half of the energy from firewood, forest and plant residues, pellets, and other agglomerates consumed in the Portuguese industry in 2019. Indeed, $69 \%$ of the energy consumed in the Portuguese pulp and paper industry in 2019 came from biomass (83\% from black liquor and the rest mainly from bark and other wood residues) [12]. This sector uses the biomass for the combined production of heat and power and sells the surplus electricity to the national grid. The power sector is an important consumer of biomass. Currently, 14 dedicated biomass-fired power plants are in operation in Portugal [13], some associated with the pulp and paper sector and supplied by Eucalyptus globulus residues.

The pressure on forests in general, and Eucalyptus globulus stands in particular, increases due to the intensification of the use of biomass for energy [14-16]. As a way of mitigating greenhouse gas emissions, there is a drive to generate more biopower and bioheat and to diversify energy products from biomass (e.g., second generation biofuels). This may lead to an increase in the prices of biomass products and spur forest owners to shorten harvest cycles or to remove more residues from the stands. Even though biomass availability is one of the main uncertainties when considering a greater biomass uptake [17], just proceeding with maximization of use as the dominant management priority has to be considered prudently [18], and sustainability issues need to be well-thought-out.

When analyzing the potential of residual biomass for energy production, the impacts of biomass removal from the forest should be considered. In the literature, not only the quantity but also the type of residues removed and site quality are identified as important factors [19-24]. In general, the larger the exports of biomass, the larger the exports of nutrients [25]. Yet, as nutrient concentration is higher in leaves, twigs, and small branches, stem harvest exports much less nutrients [25-28]. The export of biomass is especially critical in poor sites where the negative impacts are stronger, as the removal of nutrients will decrease their sink in the soil, which already has poor concentration of nutrients [24].

This paper addresses the issue of residual biomass removal in Eucalyptus globulus stands managed for pulp and paper and its impacts. Although the problem of the estimation of economically viable biomass energy potential has been tackled (e.g., [29,30]), the existing studies on residual biomass potential do not explore the amount of residues that can be removed from the stands and its relation to site quality and location. The goal of this study is the comparison, via a simulation approach, of the use of different proportions of forest residues derived from Eucalyptus globulus plantations in terms of bioenergy availability and sustainability. The use of a growth and production simulator enabled the definition of 80 different scenarios that allowed discussion of the effect of location, quantity and type of residues harvested, and site quality on the supply of biomass for energy and its environmental impacts.

The results presented in this work highlight the necessity of recognizing regional and site differences and diverse forest management options when defining the yields of residual biomass used in energy potential studies. Higher residue removal from the stands results in larger energy potentials, but also potentially leads to higher environmental impacts. 


\section{Materials and Methods}

\subsection{Geographical Scope}

The study is focused in northern and central Portugal, a country in the Iberian Peninsula in Western Europe. This region was chosen as it represents about $73 \%$ of the area of Eucalyptus globulus in Portugal (616.3 thousand hectares [2]). To evaluate the effect of climate, in particular of the number of day with precipitation equal or superior to $1 \mathrm{~mm}$, on the amount of biomass and forest residues produced, four locations were chosen: Mortágua, Carvoeiro, Aldeia do Mato, and Coruche (Figure 1, Table 1). Traditionally, site quality of the forest stands is evaluated with site index (defined as the dominant height for a target age). Site index is frequently used, as it is correlated to volume (and to biomass) and stand structure, and silvicultural practices have low effect on the dominant height [31]. For Eucalyptus globulus stands, the target age is 10 years. The four locations were chosen to address the variability of site indices and annual rainfall. Carvoeiro and Mortágua are representative of the better quality site indices (site indices varying between 16 and 28 for the former and 14 to 26 for the latter) and Aldeia do Mato and Coruche of the lower ones (site indices varying between 13 and 25 for the former and 11 to 23 for the latter). Two site indices (17 and 20) that are common to all the four locations were chosen for the analysis presented in Section 3 in order to evaluate the forest residue variability between sites and within each site.

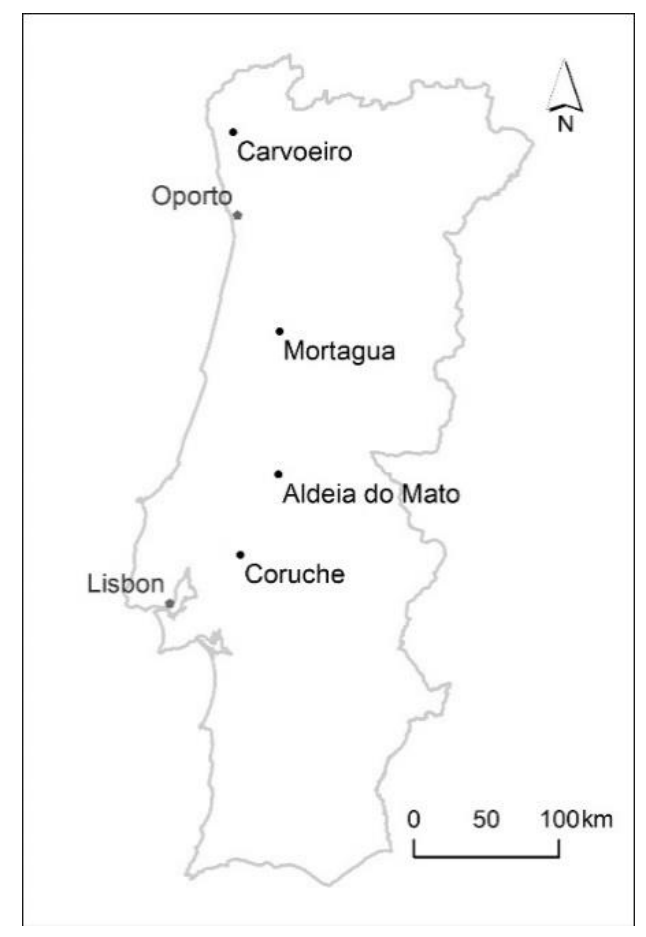

Figure 1. Map of the studied locations.

Table 1. Location (in geographical WGS84 coordinate system), altitude, annual rainfall, and site index range of the four sites.

\begin{tabular}{ccccc}
\hline Parameter & Mortágua & Carvoeiro & Aldeia do Mato & Coruche \\
\hline Latitude & 40.4201 & 41.66509 & 39.52675 & 39.02265 \\
Longitude & -8.27277 & -8.65755 & -8.28049 & -8.57961 \\
Altitude $(\mathrm{m})$ & 175 & 192 & 208 & 79 \\
Rainfall $\left(\right.$ days a $^{-1}$ ) & 118.3 & 136 & 103.5 & 83.9 \\
Site index range & $16-28$ & $14-26$ & $13-25$ & $11-23$ \\
\hline
\end{tabular}




\subsection{Biomass Production}

The production of biomass in Eucalyptus globulus stands managed for pulp and paper was estimated through simulation for the four locations and two different site indices. Of all the available models of silviculture described in the literature [32], one of the most frequently used in Portugal was chosen for this study. The model of silviculture is characterized by a density of plantation of 1250 trees ha $^{-1}$ (spacing $4 \mathrm{~m} \times 2 \mathrm{~m}$ ); rotations of 12 years; three harvest cycles, with high forest in the first and coppice in the latter two; and stump mortality of 0.1 stumps ha $\mathrm{a}^{-1} \mathrm{a}^{-1}$. The biomass was estimated using WebGlobulus simulator [33], which is based on the Globulus model of Tomé et al. [34] and Tomé et al. [35]. The Globulus model is an empirical growth and production model at stand level for even-aged and for both high forest and coppice regimes of Eucalyptus globulus stands for Portugal [34,35]. This model has two modules: (1) the initialization one, which requires as control variables the site index, density (number of trees per hectare for the high forest regime, the number of stumps and shoots per stump per hectare for the coppice regime), altitude, and the number of rainy days. This module estimates growth and production with a set of equations, function of the control variables. (2) The second module is the projection one, which predicts growth and production as function of the initialization module, the control variables, and a set of equations [34,35]. The outputs generated by the Globulus model, at a per year level, include several variables among which are above-ground biomass, total and per component (stem, bark, leaves and branches), and below-ground biomass per unit area $\left(\mathrm{Mg} \mathrm{ha}^{-1}\right)$.

Considering the types of residues from above-ground and below-ground biomass [21,36,37], two approaches were followed for the definition of the scenarios: one with removal of only above-ground biomass (AGB) and the other with the removal of above and below-ground biomass (BGB) at the end of the harvest cycle (Table 2). For the quantity of AGB residues to be removed at harvest, five alternatives were considered: $30 \%, 25 \%$, and $15 \%$ of AGB; all bark and branches and $25 \%$ of leaves; and all bark and branches and $25 \%$ of leaves and $10 \%$ of stem biomass. The latter two options considered the maintenance of $75 \%$ of the leaves in the site to reduce nutrient exports, and for the last, it was assumed that $10 \%$ of the stem biomass corresponded to biomass not suited for pulp and paper. For the scenarios where BGB removal is taken into consideration, the stump and coarse roots are removed at the end of the harvest cycle (third rotation). The four locations and two site indices and the ten different forest management strategies resulted in a total of 80 forest residues scenarios.

Table 2. Residue removal scenarios considered in this study.

\begin{tabular}{cc}
\hline Scenarios & Residual Removals \\
\hline FR1.0 & $30 \%$ of AGB \\
FR2.0 & $25 \%$ of AGB \\
FR3.0 & $15 \%$ of AGB \\
FR4.0 & $100 \%$ of bark, $100 \%$ of branch, and $25 \%$ of leaf biomass \\
FR5.0 & $100 \%$ of bark, $100 \%$ of branch, $25 \%$ of leaf, and $10 \%$ of stem biomass \\
FR1.1 & Scenario FR $1.0+100 \%$ BGB at the end of the harvest cycle \\
FR2.1 & Scenario FR2.0 $+100 \%$ BGB at the end of the harvest cycle \\
FR3.1 & Scenario FR3.0 $+100 \%$ BGB at the end of the harvest cycle \\
FR4.1 & Scenario FR4.0 $+100 \%$ BGB at the end of the harvest cycle \\
FR5.1 & Scenario FR5.0 $+100 \%$ BGB at the end of the harvest cycle \\
\hline
\end{tabular}

The examination of the differences between the forest residues estimated in each of the scenarios listed in Table 2 per location and site index and among sites indices was carried out with the nonparametric Wilcoxon comparison test, as normal distribution assumptions were not met (evaluated with Shapiro-Wilk normality test). The Wilcoxon test was done with R Statistical Software [38] for a significance level of 0.05 . 


\subsection{Energy Production}

Eucalyptus globulus residues are suitable for energy production and are already commonly used in the Portuguese power, residential, and industrial sectors. Even though other conversion processes are possible, usually thermochemical conversion (mainly combustion) is used [17]. Several studies have detailed characterizations of biomass fuels (e.g., [39-43]). Important properties for energy conversion specific for Eucalyptus globulus biomass are presented in Table 3.

Table 3. Eucalyptus globulus properties.

\begin{tabular}{|c|c|c|c|}
\hline Property & & Wood & Stump \\
\hline \multirow{6}{*}{$\begin{array}{l}\text { Chemical and structural analysis } \\
\text { (wt } \% \text { dry) }\end{array}$} & Ash & - & $0.4^{\mathrm{d}}$ \\
\hline & Extractives & - & $15.1^{\mathrm{d}}$ \\
\hline & Lignin & $22.2^{\mathrm{a}}$ & $24.8^{\mathrm{d}}$ \\
\hline & Holocellulose & - & $67.0^{\mathrm{d}}$ \\
\hline & Cellulose & $51.1^{\mathrm{a}}$ & - \\
\hline & Hemicellulose & $26.7^{\mathrm{a}}$ & - \\
\hline \multirow{3}{*}{$\begin{array}{l}\text { Proximate analysis } \\
\qquad(w t \% \text { dry })\end{array}$} & Fixed Carbon & $17.30^{\mathrm{b}}$ & $18.3^{d}$ \\
\hline & Volatile matter & $81.60^{\mathrm{b}}$ & $81.1^{\mathrm{d}}$ \\
\hline & Ash & $1.1^{b}$ & $0.6^{\mathrm{d}}$ \\
\hline \multirow{5}{*}{$\begin{array}{l}\text { Ultimate analysis } \\
\qquad(\mathrm{wt} \% \text { dry })\end{array}$} & $\mathrm{C}$ & $48.18^{b}$ & $51.0^{\mathrm{d}}$ \\
\hline & $\mathrm{H}$ & $5.92^{b}$ & $5.8^{\mathrm{d}}$ \\
\hline & $\mathrm{O}$ & $44.18^{\mathrm{b}}$ & $45.3^{\mathrm{d}}$ \\
\hline & $\mathrm{N}$ & $0.39^{b}$ & $-1, \mathrm{~d}$ \\
\hline & $\mathrm{S}$ & $0.01^{b}$ & $-2, \mathrm{~d}$ \\
\hline $\begin{array}{l}\text { Lower heating value } \\
\left(\mathrm{MJ} \mathrm{kg}^{-1}\right)(\text { dry })\end{array}$ & & $17.94^{b}$ & $17.7^{\mathrm{d}}$ \\
\hline Basic density $\left(\mathrm{g} \mathrm{cm}^{-3}\right)$ & & $0.533^{c}$ & $0.63^{d}$ \\
\hline
\end{tabular}

The chemical composition and heat content of wood and stump are similar, but particular care must be taken with separating the stumps from soil particles so that the ash is kept under acceptable levels. Mixing stumps with biomass from other tree parts is a good strategy to avoid problems with a less careful field handling of the biomass [47]. The ash content reported on Table 3 is low in accordance with what is characteristic of wood biomass [42]. As far as emissions are concerned, Vicente et al. [48] showed that, for a bubbling fluidized bed combustor, $\mathrm{CO}$ emission factors were lower when the stoichiometry used in the experiments was higher and the Eucalyptus globulus residues were allowed to leach. However, decreasing the stoichiometry or using leachate wood increased particulate emissions.

The biomass residues estimated for the four locations can be converted to energy through many different routes yielding various energy outputs [49]. In this study, it was considered that the residues would be converted to energy in a dedicated biomass-fired power plant with the characteristics of the plant that exists in the Mortágua region. The reasons for choosing this energy route and plant are two-fold: (1) First, after residential heating, in Portugal, energy from firewood and residual biomass is mostly consumed in the energy sector for the production of electricity only [10]; (2) second, the size of the Mortágua power plant is typical for Portugal. The plant has a capacity of $8.6 \mathrm{MW}_{\mathrm{e}}$, produces around $60 \mathrm{GWh} \mathrm{a}^{-1}$, and consumes about $110 \times 10^{3} \mathrm{t}$ of biomass annually [50,51]. Its maximum biomass reference flow rate is $12.2 \mathrm{t} \mathrm{h}^{-1}$ for the maximum load with a reference moisture of $40 \%$ [52]. The Mortágua power plant was designed to operate $7800 \mathrm{~h} \mathrm{a}^{-1}$ which, at the maximum reference flow rate, corresponds to a consumption of around $60 \times 10^{3} \mathrm{Mg}$ dry a ${ }^{-1}$ of biomass. This is the amount that will be considered in this study as the biomass demand for the different scenarios analyzed. 


\section{Results}

\subsection{Biomass Production}

The complete results for the 80 scenarios are presented in Appendix A and in this section, the most important aspects are highlighted. The section starts with the presentation of the results obtained for the four locations, 10 forest management options, and a site index of 20 (Table A1). Then, results for a site index of 17 are presented.

The location that produces more above-ground biomass is Carvoeiro, with a total production of $351.6 \mathrm{Mg} \mathrm{ha}^{-1}$ per harvest cycle when a site index of 20 is considered, while the region that produces less is Coruche, with a production around $12 \%$ lower than that of Carvoeiro (Figure 2). The same is true for the below-ground biomass, which represents about $20 \%$ of all the biomass in the stand, and for the residual biomass obtained in the different scenarios.

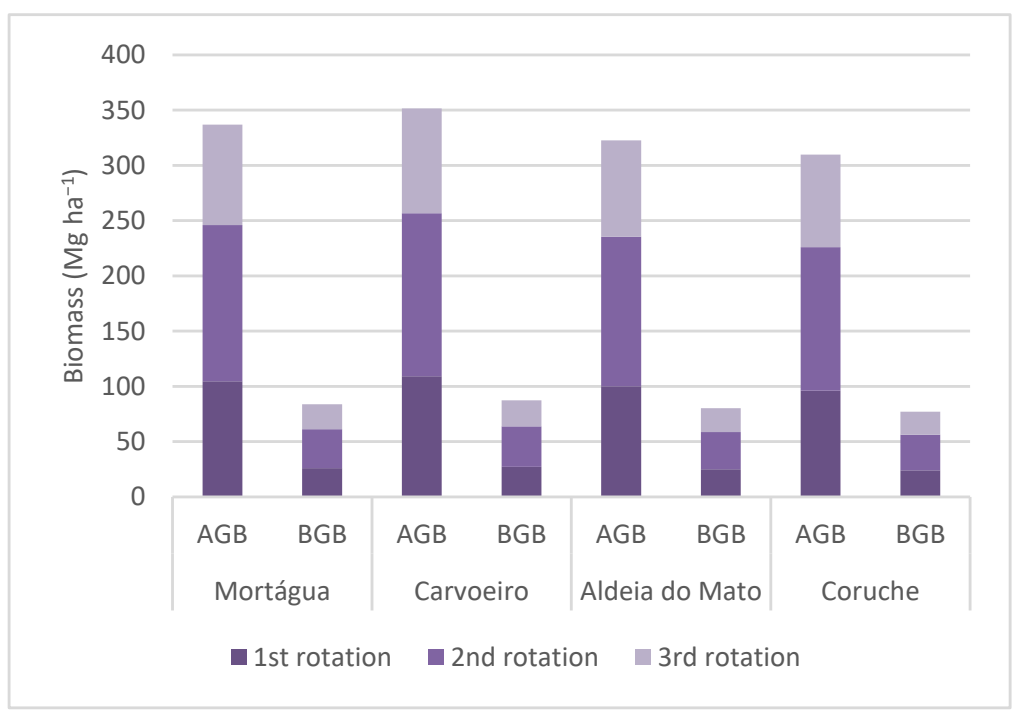

Figure 2. Total above-ground and below-ground biomass for each location (site index 20) and harvest cycle.

Figure 3 presents the biomass harvested per hectare and per harvest cycle for the most productive region, Carvoeiro, and for each of the forest-management scenarios considered. Similar trends are observed in the other three regions (the complete results are presented in Table A1). For the four locations, the mass of forest residues differed significantly between scenarios (all, $p>0.05$ ).

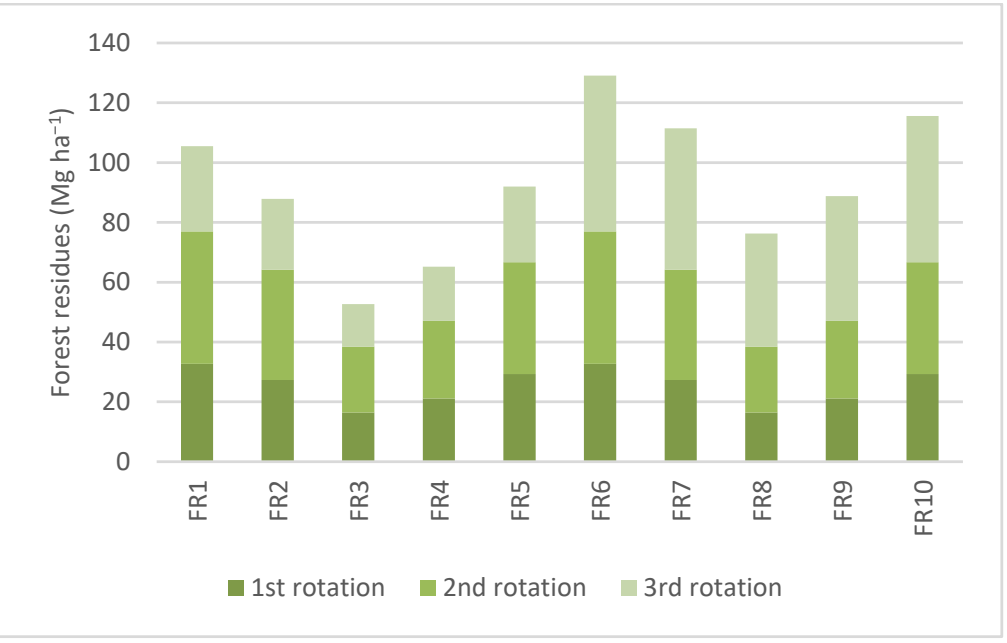

Figure 3. Biomass residues harvested for Carvoeiro (site index 20) and harvest cycle. 
When only above-ground biomass is harvested (FR1.0 to FR5.0), there is a trend towards the increase of forest residues from the first to the second rotation and a decrease from the former to the third harvest. On the other hand, when stumps and roots are removed (FR1.1 to FR5.1), the quantities of residues are larger in the last cut. On average, in that cut, 83 to $166 \%$ more mass of residues is obtained than when only above-ground biomass is removed, depending on the location and forest management scenario considered. However, this option also corresponds to the least conservative option of site fertility maintenance.

Removing all bark, all branches, and $25 \%$ of the leaves with or without below-ground biomass removal (scenarios FR4.0 and FR4.1) generates a quantity of residues between that of scenarios where 25 and $15 \%$ of the above-ground is removed with or without BGB removal (respectively, scenarios FR2.0 and FR3.0 with no BGB removal, and FR2.1 and FR3.1 with BGB removal). If, additionally, 10\% of stem is removed (scenarios FR5.0 and FR5.1), the quantities of forest residues are slightly higher than those of the scenarios where $25 \%$ of the biomass is removed (scenarios FR2.0 and FR2.1).

The highest amount of residues is attained when $30 \%$ of the above-ground biomass and $100 \%$ of the below-ground biomass are removed (FR1.1) and the lowest when 15\% of the above-ground biomass is removed. When comparing these two forest management options for the same location, on average, for the entire harvest cycle, the difference in residues that can be harvested is around $60 \%$.

To analyze the impact of site index on the amount of biomass that can be harvested in the four locations, forty additional scenarios with a site index of 17 were considered. The complete results are presented in Table A1 and the central aspects presented here. The main findings for the analysis of the impact of site index are similar to the ones presented for a higher site index of 20:

1. The location that produces more total and residual biomass is the one with more rainy days per year (Carvoeiro), while the location with the lowest precipitation (Coruche) is the one that produces less biomass (Figure 4);

2. The second cut generates more residues than the first one, but if no BGB is harvested, the final cut is the one with the lowest generation of residues (Figures 5 and 6);

3. However, if BGB is harvested on the final cut, this is the cut that generates most residues (Figures 5 and 6);

4. The highest amount of residues is attained for the option where $30 \%$ of the AGB and $100 \%$ of the BGB are removed (FR1.1) and the lowest when $15 \%$ of the AGB is removed from the stands (FR3.0) (Figure 5).

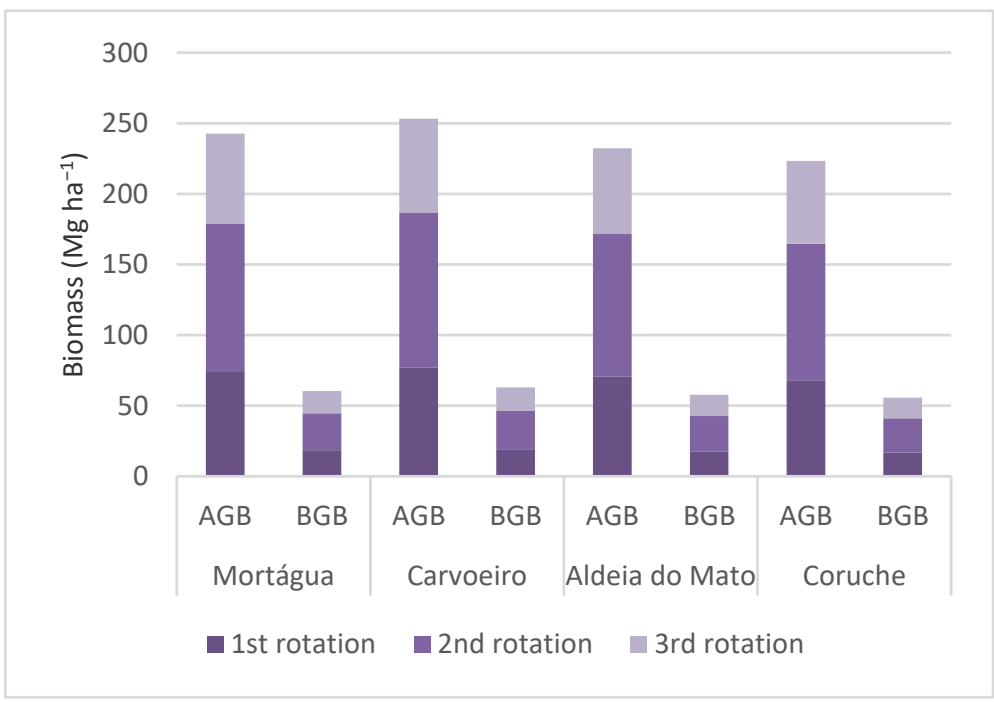

Figure 4. Total above-ground and below-ground biomass for each location (site index 17) and harvest cycle. 


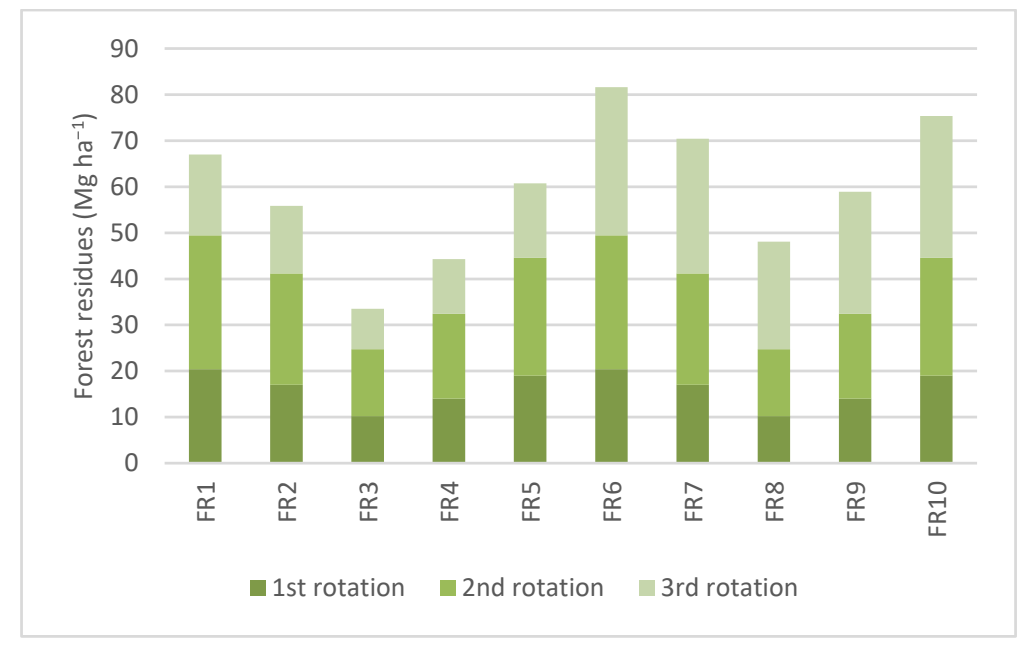

Figure 5. Biomass residues harvested for Coruche (site index 17) and harvest cycle.

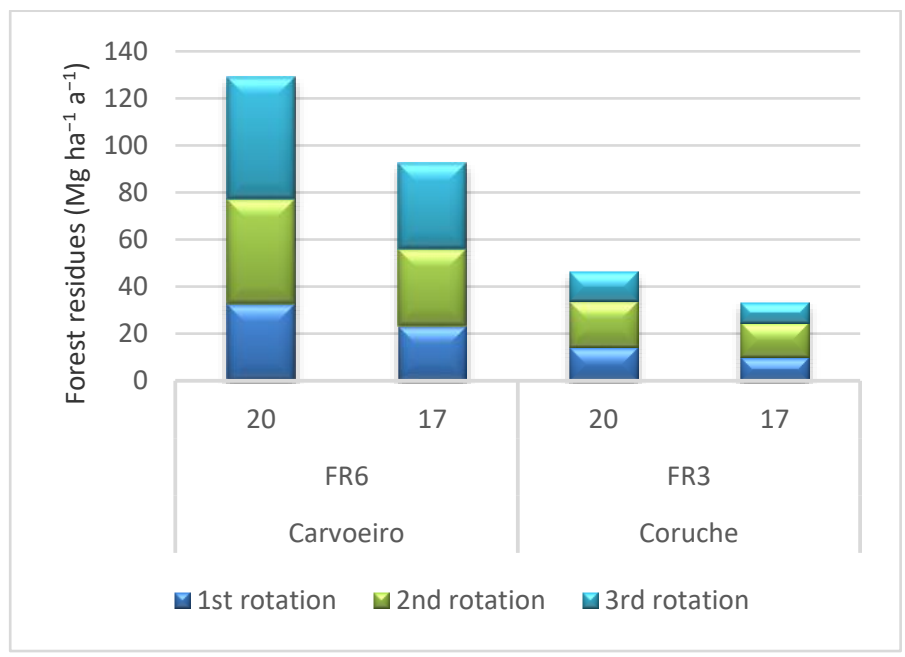

Figure 6. Biomass residues harvested for Carvoeiro (FR1.1) and Coruche (FR3.0) and harvest cycle.

Figure 5 shows the results for one location only (the complete results can be seen in Table A1). This time, the less productive location was chosen for the graphical presentation of results, but the other locations present the same trend. As in the case of the results obtained for the higher site index, for a site index of 17 , the mass of forest residues differed significantly between scenarios for the four locations (all, $p>0.05$ ). Additionally, the comparison between the various results for the two site indexes also showed significant differences (all, $p>0.05$ ).

On average, for all the forest management scenarios, the reduction of the site index from 20 to 17 leads to a $37 \%$ decrease in the amount of residues generated. There are no significant differences on the magnitude of the decrease among locations, i.e., the difference of biomass residues harvested in lower and higher site index is similar for the four regions analyzed. However, for all the scenarios, the amount of residual biomass that can be harvested in the second cut is not as dependent on site index as the biomass harvested in the other two cuts (on average, the amount of residues produced in the second cut in the stands with site index 17 is $32 \%$ lower than those with site index 20 , while the difference is around $40 \%$ for the first and third cuts).

For a clear picture of the combined impact of the forest management strategy and of location, Figure 6 presents side by side the results for the scenario that generates more residues (Carvoeiro, FR1.1) and the one than generates less (Coruche, FR3.0). The difference in residues that can be removed from the stands per harvest cycle in these two extreme scenarios is evident. 


\subsection{Energy Production}

After calculating the amount of residues that may be harvested in each scenario, the area of Eucalyptus globulus plantations needed to supply biomass to a $9 \mathrm{MW}_{\mathrm{e}}$ power plant for one year was determined. The complete results are presented in Table A2 in the Appendix A.

In the most productive location, Carvoeiro, and for the scenario where more residues are obtained (FR1.1; site index 20), if a final cut (at the end of the third rotation, at 36 years) in an area of 1096 ha of Eucalyptus globulus was made, the residual biomass obtained would be enough to supply a $9 \mathrm{MW}_{\mathrm{e}}$ power plant for one year. This area would need to be $14 \%$ larger in Coruche, the less productive location, if a similar quality site was considered (FR1.1; site index 20). For the FR1.1 scenario and a lower quality site in Coruche (site index 17), the area needed to supply the power plant would need to be $62 \%$ larger than in Carvoeiro in a higher quality site (site index 20). In scenario FR1.1, it is in the final cut where the largest amount of residues is removed. The other two cuts present lower residue productivities because the stumps are not removed. When compared with FR1.0, the amount of residues in the first and second rotation are equal; only in the third rotation does the removal of BGB derive an increase of residues of about $83 \%$ (for a site index of 20). For the region of Carvoeiro with the same site index, if the $9 \mathrm{MW}_{\mathrm{e}}$ power plant was supplied during one year with residues obtained in the first cut, 59\% more area (1746 ha) would be needed than if the residues were obtained in the third cut. For the second cut, these values would be $18 \%$ and 1289 ha.

The area needed to supply the power plant in the less productive location and scenario is considerably larger than in the most productive. This corresponds to scenario FR3.0, the Coruche region, with a site index of 17 and the residues obtained in the third cut. If no below-ground biomass is collected, and $15 \%$ of the total above-ground biomass (FR3.0) is removed in a stand with site index of 17 in the region of Coruche, an area of 6496 ha would need to be cut so that the power plant would have a supply of residual biomass for a year. This would represent almost a sixfold increase compared to the case where the power plant was supplied with residues harvested in the last cut in a stand with site index of 20 in Carvoeiro for scenario FR1.1. These extreme scenarios are presented in Figure 7.

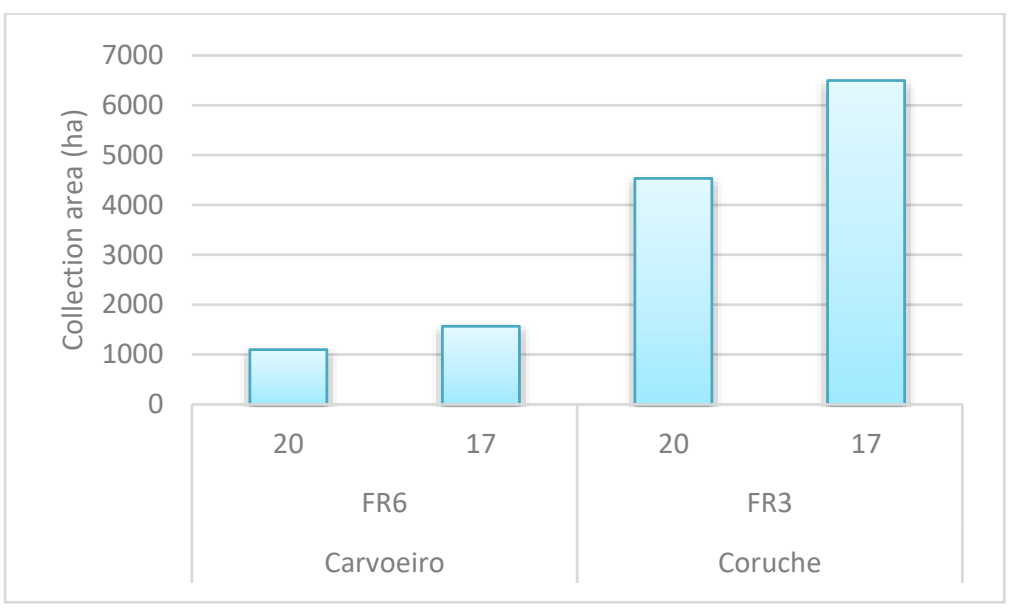

Figure 7. Area needed to supply biomass to a 9 MWe power plant for one year in Carvoeiro (site index 20, FR1.1) and Coruche (site index 17, FR3.0).

The results presented in Table A2 and Figure 7 show the area needed to supply the $9 \mathrm{MW}_{\mathrm{e}}$ power plant for one year with the residues obtained in cuts made every 12 years. To guarantee a continuous supply of biomass to the power plant, a considerably larger area would be needed. Ideally, the region that generates residues for the power plant should be characterized by stands of different ages so that cuts can be made every year and the yearly amount of residues is approximately constant. To obtain the yearly average of 
residues removed under the different scenarios, the data on Table A1 were divided by the length of the rotation. On average, the amount of residues obtained lies in the range 0.7 to $4.3 \mathrm{Mg} \mathrm{ha}^{-1} \mathrm{a}^{-1}$, depending on the region, site quality, and on the forest management option. For Coruche, the less productive region, $0.7 \mathrm{Mg} \mathrm{ha}^{-1} \mathrm{a}^{-1}$ of residues are obtained if $15 \%$ of the above-ground biomass is removed from a site with the lowest quality analyzed, while up to $2.7 \mathrm{Mg} \mathrm{ha}^{-1} \mathrm{a}^{-1}$ are available when $30 \%$ of the above-ground biomass and all of the below-ground biomass are removed in a site with the same quality. For the most productive location with the highest site quality, Carvoeiro, these values are, respectively, 1.2 and $4.3 \mathrm{Mg} \mathrm{ha}^{-1} \mathrm{a}^{-1}$, depending on the amount of residues removed from the plot.

Care must be taken when using single-valued residue productivities in energy potential studies. The results presented above show the importance of the site index and location and, above all, of the forest management option in the capacity of Eucalyptus globulus stands that are managed for pulp and paper supplying residual biomass to a biomass-fired power plant. The results show that, when estimating the energy potential of biomass, it is essential to consider the productivity of the site, characteristics of the region, and the forest management strategy followed. Depending on these factors, the differences in biomass potential for energy can be significant.

\section{Discussion}

The results show a trend towards higher yields of residues for better quality sites (higher site index and higher precipitation). This is the result of the higher growth rate of biomass because of the higher availability of water and nutrients in the soil [26]. Compared to other species that are common in Portugal and that have similar transpiration, evapotranspiration, and water consumption (e.g., Pinus pinaster), Eucalyptus globulus is characterized by lower losses of precipitation by interception (of the leaves); these traits are related to the climatic region, stand crown cover, and leaf area index. As a result, in Eucalyptus globulus stands, more water reaches the soil [53] and is available for the trees. For example, the second most common tree species in Portugal, Pinus pinaster, has acicular leaves and intercepts more rainfall than Eucalyptus globulus, which has lanceolate leaves; this results in lower amounts of water reaching the soil in stands of the former species than those of the latter one [53]. Overall, the productivity both in terms of wood and residues seems to be linked with the site index and mean annual precipitation, as it can be seen when the yields of the four locations are compared.

The amount of residues removed from the stands can influence the soil productive potential. It is known that the highest concentration of nutrients is in the leaves, twigs, and small branches, while the larger branches and stem have the lowest nutrient content $[26,27,54]$. Thus, potentially, the larger the biomass residue removal, the larger the exports of nutrients [25]. However, Madeira et al. [26] found that, for Eucalyptus globulus plantations in Portugal, the removal of forest residues did not affect the tree growth and its nutritional status and the soil carbon sequestration. Similar results for other species in high forest systems are conveyed by Persson and Egnell [54]. Madeira et al. [55] studied the removal and maintenance (incorporation in the soil and distribution on the soil surface) of forest residues with and without nitrogen fertilization in Eucalyptus globulus stands. The authors concluded that both removal and maintenance of residues resulted in similar growth and nutrition status. Yet, fertilization, regardless of the residue treatment, resulted in higher growth, because fertilization enabled trees to reach higher nitrogen uptake rates.

Stump harvest (including stump and coarse roots) seems to have few, if any, effects on the soil's organic carbon content and on the growth rate in the short and medium terms; yet it results in the exposure of mineral soil [54]. However, intensive soil mobilization results in the same effects. Madeira et al. [26] convey that, for Eucalyptus globulus plantations with eight years in Portugal, stump harvest had no effect on soil productive potential except in very poor soils. This can be explained by the fact that Eucalyptus globulus adapts well to poor sites with low nutrients content by the root symbiosis (mycorrhizas) and by the efficient internal use of nutrients [26]. 
The effects of forest residue removal on understory vegetation were studied by Carneiro et al. [56]. In general, species richness, vegetation cover, and biomass of the understory varied slightly whether or not the residues were removed from the stands. This study shows a trend towards a higher number and proportion of species when residues are removed in contrast with spreading forest residues in the soil. Also, the incorporation of residues by arrowing favored the species that reproduce by rhizomes because arrowing fragmented the rhizomes, and promoted the increase of the number and vegetation cover of these species. Overall, Carneiro et al. [56] concluded that residue removal did not show a trend towards negative effects in the understory vegetation.

Several silvicultural practices that can be used to mitigate the effects of stem and residue harvest, which contribute to the system sustainability, are: (1) Coppices use frequently clearcutting systems. The reduction of the extension of the cut areas can reduce external drainage, especially up to the third year after harvest when it is the highest, thus also contributing to reduce the risk of erosion. This is especially important at the end of the third rotation. In the first and second rotation harvest, the root systems remain alive, resprout occurs shortly after the harvest, and the sprouts grow vigorously, thus minimizing the external drainage and the erosion risk [53]. (2) The maintenance of the soil organic layers reduces, to a minimum, the disturbances caused by harvest in the nutrient cycles, soil surface, and thermic and hydrological regimes [26]. (3) Less intensive soil mobilization prior to plantation can help to maintain the soil productive potential [26]. (4) The maintenance of the leaves and twigs on the site reduces the export of nutrients [26].

Overall, forest residue removal has low impacts on Eucalyptus globulus stands' productivity, diversity, and system sustainability. Yet, the impacts increase with the decrease of site index and the increase of the amounts of residues removed, especially the removal of those with the highest nutrient quantities (e.g., leaves). For the two site indices evaluated $(17,20)$, the scenarios with the maintenance of $75 \%$ of the leaves and no stump removal (FR4.0, FR5.0) are the most conservative for site productivity. Those without stump removal (FR1.0 to FR5.0) tend to be better suited to preserve carbon and nutrient pools in the soil than those with stump removal (FR1.1 to FR5.1). However, due to Eucalyptus globulus plasticity and adaptation, the stump removal does not seem to reduce growth and yield. Also, stump removal has the advantage of making replantation operations easier and less expensive.

Author Contributions: Conceptualization, I.M. and A.C.G.; methodology, I.M. and A.C.G.; formal analysis, I.M. and A.C.G.; investigation, I.M. and A.C.G.; data curation, I.M. and A.C.G.; writingoriginal draft preparation, I.M. and A.C.G.; writing-review \& editing, I.M. and A.C.G.; Visualization, I.M. and A.C.G. All authors have read and agreed to the published version of the manuscript.

Funding: This research was funded by the European Fund for Regional Development (ref. 0753_CILIFO_5_E) and by National Funds through FCT_Foundation for Science and Technology under Project UIDB/05183/2020 and Project UIDB/50022/2020 (through IDMEC, under LAETA).

Institutional Review Board Statement: Not applicable.

Informed Consent Statement: Not applicable.

Conflicts of Interest: The authors declare no conflict of interest.

\section{Appendix A}

Table A1 presents the total and residual biomass that can be harvested at the four locations considered under the ten biomass removal scenarios defined and for two different site indices (17 and 20). 
Table A1. Biomass and forest residues for each location, for site indices 17 and 20, per harvest cycle $\left(\mathrm{Mg} \mathrm{ha}^{-1}\right)$.

\begin{tabular}{|c|c|c|c|c|c|c|c|c|c|c|c|c|c|}
\hline Location & Rotation & AGB & BGB & FR1.0 & FR2.0 & FR3.0 & FR4.0 & FR5.0 & FR1.1 & FR2.1 & FR3.1 & FR4.1 & FR5.1 \\
\hline \multicolumn{14}{|c|}{ Site index $=20$} \\
\hline \multirow{3}{*}{ Mortágua } & 1 & 104.5 & 26.0 & 31.4 & 26.1 & 15.7 & 20.2 & 28.1 & 31.4 & 26.1 & 15.7 & 20.2 & 28.1 \\
\hline & 2 & 141.4 & 35.2 & 42.4 & 35.4 & 21.2 & 25.1 & 36.0 & 42.4 & 35.4 & 21.2 & 25.1 & 36.0 \\
\hline & 3 & 90.9 & 22.6 & 27.3 & 22.7 & 13.6 & 17.3 & 24.2 & 49.9 & 45.3 & 36.2 & 39.9 & 46.8 \\
\hline \multirow{3}{*}{ Carvoeiro } & 1 & 109.1 & 27.1 & 32.7 & 27.3 & 16.4 & 21.1 & 29.3 & 32.7 & 27.3 & 16.4 & 21.1 & 29.3 \\
\hline & 2 & 147.6 & 36.7 & 44.3 & 36.9 & 22.1 & 26.0 & 37.4 & 44.3 & 36.9 & 22.1 & 26.0 & 37.4 \\
\hline & 3 & 94.9 & 23.6 & 28.5 & 23.7 & 14.2 & 18.1 & 25.3 & 52.1 & 47.3 & 37.8 & 41.7 & 48.9 \\
\hline \multirow{3}{*}{ Aldeia do Mato } & 1 & 100.0 & 24.9 & 30.0 & 25.0 & 15.0 & 19.4 & 26.9 & 30.0 & 25.0 & 15.0 & 19.4 & 26.9 \\
\hline & 2 & 135.5 & 33.7 & 40.7 & 33.9 & 20.3 & 24.0 & 34.4 & 40.7 & 33.9 & 20.3 & 24.0 & 34.4 \\
\hline & 3 & 87.0 & 21.6 & 26.1 & 21.8 & 13.1 & 16.6 & 23.1 & 47.7 & 43.4 & 34.7 & 38.2 & 44.7 \\
\hline \multirow{3}{*}{ Coruche } & 1 & 96.1 & 23.9 & 28.8 & 24.0 & 14.4 & 18.6 & 25.9 & 28.8 & 24.0 & 14.4 & 18.6 & 25.9 \\
\hline & 2 & 129.9 & 32.3 & 39.0 & 32.5 & 19.5 & 23.1 & 33.1 & 39.0 & 32.5 & 19.5 & 23.1 & 33.1 \\
\hline & 3 & 83.7 & 20.8 & 25.1 & 20.9 & 12.6 & 16.0 & 22.3 & 45.9 & 41.7 & 33.4 & 36.8 & 43.1 \\
\hline \multicolumn{14}{|c|}{ Site index $=17$} \\
\hline \multirow{3}{*}{ Mortágua } & 1 & 73.9 & 18.4 & 22.2 & 18.5 & 11.1 & 15.1 & 20.5 & 22.2 & 18.5 & 11.1 & 15.1 & 20.5 \\
\hline & 2 & 105.2 & 26.2 & 31.6 & 26.3 & 15.8 & 19.9 & 27.8 & 31.6 & 26.3 & 15.8 & 19.9 & 27.8 \\
\hline & 3 & 63.6 & 15.8 & 19.1 & 15.9 & 9.5 & 12.9 & 17.5 & 34.9 & 31.7 & 25.3 & 28.7 & 33.3 \\
\hline \multirow{3}{*}{ Carvoeiro } & 1 & 77.1 & 19.2 & 23.1 & 19.3 & 11.6 & 15.8 & 21.4 & 23.1 & 19.3 & 11.6 & 15.8 & 21.4 \\
\hline & 2 & 109.8 & 27.3 & 32.9 & 27.5 & 16.5 & 20.7 & 28.9 & 32.9 & 27.5 & 16.5 & 20.7 & 28.9 \\
\hline & 3 & 66.4 & 16.5 & 19.9 & 16.6 & 10.0 & 13.3 & 18.2 & 36.4 & 33.1 & 26.5 & 29.8 & 34.7 \\
\hline \multirow{3}{*}{ Aldeia do Mato } & 1 & 70.7 & 17.6 & 21.2 & 17.7 & 10.6 & 14.4 & 19.6 & 21.2 & 17.7 & 10.6 & 14.4 & 19.6 \\
\hline & 2 & 100.9 & 25.1 & 30.3 & 25.2 & 15.1 & 19.2 & 26.7 & 30.3 & 25.2 & 15.1 & 19.2 & 26.7 \\
\hline & 3 & 60.8 & 15.1 & 18.2 & 15.2 & 9.1 & 12.3 & 16.8 & 33.3 & 30.3 & 24.2 & 27.4 & 31.9 \\
\hline \multirow{3}{*}{ Coruche } & 1 & 68.0 & 16.9 & 20.4 & 17.0 & 10.2 & 14.0 & 19.0 & 20.4 & 17.0 & 10.2 & 14.0 & 19.0 \\
\hline & 2 & 96.8 & 24.1 & 29.0 & 24.2 & 14.5 & 18.4 & 25.6 & 29.0 & 24.2 & 14.5 & 18.4 & 25.6 \\
\hline & 3 & 58.6 & 14.6 & 17.6 & 14.7 & 8.8 & 11.9 & 16.2 & 32.2 & 29.3 & 23.4 & 26.5 & 30.8 \\
\hline
\end{tabular}

Table A2 shows the area of Eucalyptus globulus plantations needed to supply biomass to a $9 \mathrm{MW}_{\mathrm{e}}$ power plant during one year for the different scenarios considered in this work.

Table A2. Area needed to supply biomass to a $9 \mathrm{MW}_{\mathrm{e}}$ power plant for one year (ha) for the different scenarios analyzed.

\begin{tabular}{|c|c|c|c|c|c|c|c|c|c|c|c|}
\hline Location & Rotation & FR1.0 & FR2.0 & FR3.0 & FR4.0 & FR5.0 & FR1.1 & FR2.1 & FR3.1 & FR4.1 & FR5.1 \\
\hline \multicolumn{12}{|c|}{ Site index $=20$} \\
\hline \multirow{3}{*}{ Mortágua } & 1 & 1818 & 2188 & 3637 & 2827 & 2032 & 1818 & 2188 & 3637 & 2827 & 2032 \\
\hline & 2 & 1347 & 1613 & 2693 & 2275 & 1586 & 1347 & 1613 & 2693 & 2275 & 1586 \\
\hline & 3 & 2091 & 2515 & 4198 & 3300 & 2359 & 1144 & 1260 & 1577 & 1431 & 1220 \\
\hline \multirow{3}{*}{ Carvoeiro } & 1 & 1746 & 2091 & 3481 & 2706 & 1949 & 1746 & 2091 & 3481 & 2706 & 1949 \\
\hline & 2 & 1289 & 1547 & 2584 & 2196 & 1527 & 1289 & 1547 & 2584 & 2196 & 1527 \\
\hline & 3 & 2003 & 2409 & 4021 & 3154 & 2257 & 1096 & 1207 & 1510 & 1369 & 1168 \\
\hline \multirow{3}{*}{ Aldeia do Mato } & 1 & 1903 & 2284 & 3806 & 2943 & 2123 & 1903 & 2284 & 3806 & 2943 & 2123 \\
\hline & 2 & 1403 & 1684 & 2813 & 2379 & 1660 & 1403 & 1684 & 2813 & 2379 & 1660 \\
\hline & 3 & 2188 & 2619 & 4358 & 3440 & 2472 & 1197 & 1316 & 1645 & 1495 & 1277 \\
\hline \multirow{3}{*}{ Coruche } & 1 & 1983 & 2379 & 3965 & 3070 & 2204 & 1983 & 2379 & 3965 & 3070 & 2204 \\
\hline & 2 & 1464 & 1757 & 2928 & 2472 & 1725 & 1464 & 1757 & 2928 & 2472 & 1725 \\
\hline & 3 & 2275 & 2732 & 4531 & 3569 & 2560 & 1244 & 1369 & 1709 & 1552 & 1325 \\
\hline \multicolumn{12}{|c|}{ Site index $=17$} \\
\hline \multirow{3}{*}{ Mortágua } & 1 & 2575 & 3090 & 5151 & 3781 & 2785 & 2575 & 3090 & 5151 & 3781 & 2785 \\
\hline & 2 & 1809 & 2171 & 3618 & 2866 & 2055 & 1809 & 2171 & 3618 & 2866 & 2055 \\
\hline & 3 & 2992 & 3591 & 5985 & 4435 & 3256 & 1637 & 1801 & 2253 & 1991 & 1713 \\
\hline \multirow{3}{*}{ Carvoeiro } & 1 & 2468 & 2962 & 4937 & 3625 & 2669 & 2468 & 2962 & 4937 & 3625 & 2669 \\
\hline & 2 & 1733 & 2080 & 3467 & 2758 & 1974 & 1733 & 2080 & 3467 & 2758 & 1974 \\
\hline & 3 & 2866 & 3440 & 5733 & 4285 & 3138 & 1568 & 1725 & 2158 & 1914 & 1646 \\
\hline \multirow{3}{*}{ Aldeia do Mato } & 1 & 2692 & 3230 & 5384 & 3958 & 2915 & 2692 & 3230 & 5384 & 3958 & 2915 \\
\hline & 2 & 1886 & 2263 & 3772 & 2978 & 2138 & 1886 & 2263 & 3772 & 2978 & 2138 \\
\hline & 3 & 3130 & 3756 & 6261 & 4633 & 3404 & 1713 & 1884 & 2357 & 2082 & 1791 \\
\hline \multirow{3}{*}{ Coruche } & 1 & 2799 & 3359 & 5598 & 4078 & 3011 & 2799 & 3359 & 5598 & 4078 & 3011 \\
\hline & 2 & 1966 & 2359 & 3932 & 3103 & 2229 & 1966 & 2359 & 3932 & 3103 & 2229 \\
\hline & 3 & 3248 & 3897 & 6496 & 4798 & 3529 & 1774 & 1952 & 2441 & 2155 & 1855 \\
\hline
\end{tabular}




\section{References}

1. Potts, B.M.; Vaillancourt, R.E.; Jordan, G.J.; Dutkowski, G.W.; Costa e Silva, J.; McKinnon, G.E.; Steane, D.A.; Volker, P.W.; Lopez, G.A.; Apiolaza, L.A.; et al. Exploration of the Eucalyptus globulus Gene Pool. In Eucalyptus in a Changing World, Proceedings of the IUFRO Conference, Aveiro, Portugal, 11-15 October 2004; Borralho, N.M.G., Pereira, J.S., Marques, C., Coutinho, J., Madeira, M., Tomé, M., Eds.; RAIZ, Instituto Investigação de Floresta e Papel: Aveiro, Portugal, 2004; pp. 46-61.

2. IFN6. $6^{\circ}$ Inventário Florestal Nacional; Instituto da Conservação da Natureza e das Florestas: Lisbon, Portugal, $2015 ;$ p. 26.

3. Águas, A.; Ferreira, A.; Maia, P.; Fernandes, P.M.; Roxo, L.; Keizer, J.; Silva, J.S.; Rego, F.C.; Moreira, F. Natural establishment of Eucalyptus globulus Labill. in burnt stands in Portugal. For. Ecol. Manag. 2014, 323, 47-56. [CrossRef]

4. APA. National Forestry Accounting Plan. Portugal 2021-2025; APA-Agência Portuguesa de Ambiente: Lisbon, Portugal, 2020.

5. Martire, S.; Castellani, V.; Sala, S. Carrying capacity assessment of forest resources: Enhancing environmental sustainability in energy production at local scale. Resour. Conserv. Recycl. 2015, 94, 11-20. [CrossRef]

6. Pérez, S.; Renedo, C.; Ortiz, A.; Mañana, M.; Silió, D. Energy evaluation of the Eucalyptus globulus and the Eucalyptus nitens in the north of Spain (Cantabria). Thermochim. Acta 2006, 451, 57-64. [CrossRef]

7. Rothe, A.; Moroni, M.; Neyland, M.; Wilnhammer, M. Current and potential use of forest biomass for energy in Tasmania. Biomass-Bioenergy 2015, 80, 162-172. [CrossRef]

8. Dias, J.; Azevedo, J. Evaluation of Biomass Residuals in Portugal Mainland. In New and Renewable Energy Technologies for Sustainable Development; CRC Press: London, UK, 2020; pp. 215-228.

9. López-Rodríguez, F.; Atanet, C.P.; Blázquez, F.C.; Celma, A.R. Spatial assessment of the bioenergy potential of forest residues in the western province of Spain, Caceres. Biomass-Bioenergy 2009, 33, 1358-1366. [CrossRef]

10. DGEG. Balanço Energético 2019; DGEG: Lisboa, Portugal, 2020; p. 17.

11. Malico, I.; Gonçalves, A.C.; Sousa, A.M.O. Evergreen oak biomass residues for firewood. In Forest Biomass-From Trees to Energy; Gonçalves, A.C., Sousa, A., Malico, I., Eds.; IntechOpen: London, UK, 2021; pp. 87-103. [CrossRef]

12. CELPA. Boletim Estatístico 2019; CELPA—Associação da Indústria Papeleira: Lisbon, Portugal, 2020; p. 368.

13. Database of Electric Power Plants Based on Renewable Energy Sources. Available online: https://e2p.inegi.up.pt/ (accessed on 14 March 2021).

14. Barreiro, S.; Tomé, M. Analysis of the Impact of the Use of Eucalyptus Biomass for Energy on Wood Availability for Eucalyptus Forest in Portugal: A Simulation Study. Ecol. Soc. 2012, 17, 14. [CrossRef]

15. Bryngemark, E. Second generation biofuels and the competition for forest raw materials: A partial equilibrium analysis of Sweden. For. Policy Econ. 2019, 109, 102022. [CrossRef]

16. Lauri, P.; Forsell, N.; Gusti, M.; Korosuo, A.; Havlik, P.; Obersteiner, M. Global Woody Biomass Harvest Volumes and Forest Area Use Under Different SSP-RCP Scenarios. J. For. Econ. 2019, 34, 285-309. [CrossRef]

17. Malico, I.; Pereira, R.N.; Gonçalves, A.C.; Sousa, A.M.O. Current status and future perspectives for energy production from solid biomass in the European industry. Renew. Sustain. Energy Rev. 2019, 112, 960-977. [CrossRef]

18. Hesselink, T.P. Increasing pressures to use forest biomass: A conservation viewpoint. For. Chron. 2010, 86, 28-35. [CrossRef]

19. Cook, J.; Beyea, J. Bioenergy in the United States: Progress and possibilities11Based on the final report for NREL Subcontract No. ACD-5-15212-01 with the National Audubon Society. Biomass-Bioenergy 2000, 18, 441-455. [CrossRef]

20. Swank, W.; Vose, J.; Elliott, K. Long-term hydrologic and water quality responses following commercial clearcutting of mixed hardwoods on a southern Appalachian catchment. For. Ecol. Manag. 2001, 143, 163-178. [CrossRef]

21. Berndes, G.; Hoogwijk, M.; Broek, R.V.D. The contribution of biomass in the future global energy supply: A review of 17 studies. Biomass-Bioenergy 2003, 25, 1-28. [CrossRef]

22. Belleau, A.; Brais, S.; Paré, D. Soil Nutrient Dynamics after Harvesting and Slash Treatments in Boreal Aspen Stands. Soil Sci. Soc. Am. J. 2006, 70, 1189-1199. [CrossRef]

23. Shepard, J.P. Water quality protection in bioenergy production: The US system of forestry Best Management Practices. BiomassBioenergy 2006, 30, 378-384. [CrossRef]

24. Egnell, G. A review of Nordic trials studying effects of biomass harvest intensity on subsequent forest production. For. Ecol. Manag. 2017, 383, 27-36. [CrossRef]

25. Raulund-Rasmussen, K.; Stupak, I.; Clarke, N.; Callesen, I.; Helmisaari, H.S.; Karltun, E.; Varnagiryte-Kabasinskiene, I. Effects of very intensive forest biomass harvesting on short and long term site productivity. In Sustainable Use of Forest Biomass for Energy: A Synthesis with Focus on the Baltic and Nordic Region. Managing Forest Ecosystems; Röser, D., Asikainen, A., Raulund-Rasmussen, K., Stupak, I., Eds.; Springer: Dordrecht, The Netherlands, 2008; Volume 12, pp. 29-78. [CrossRef]

26. Madeira, M.; Cortez, N.; Azevedo, C.; Magalhães, M.C.; Ribeiro, C.; Fabião, A. As plantações de eucalipto e o solo. In O Eucaliptal em Portugal; Alves, A.M., Pereira, J.S., Silva, J.M.N., Eds.; ISAPress: Lisbon, Portugal, 2007; pp. 137-174.

27. Pyttel, P.L.; Köhn, M.; Bauhus, J. Effects of different harvesting intensities on the macro nutrient pools in aged oak coppice forests. For. Ecol. Manag. 2015, 349, 94-105. [CrossRef]

28. Junior, H.J.E.; De Melo, R.X.; Sartori, M.M.P.; Guerra, S.P.S.; Ballarin, A.W. Sustainable use of eucalypt biomass grown on short rotation coppice for bioenergy. Biomass-Bioenergy 2016, 90, 15-21. [CrossRef]

29. Fernandes, U.; Costa, M. Potential of biomass residues for energy production and utilization in a region of Portugal. BiomassBioenergy 2010, 34, 661-666. [CrossRef] 
30. Malico, I.; Carrajola, J.; Gomes, C.P.; Lima, J. Biomass residues for energy production and habitat preservation. Case study in a montado area in Southwestern Europe. J. Clean. Prod. 2016, 112, 3676-3683. [CrossRef]

31. Burkhart, H.E.; Tomé, M. Modeling Forest Trees and Stands; Springer Science \& Business Media: Berlin/Heidelberg, Germany, 2012.

32. Correia, A.V.; Oliveira, A.C. Principais Espécies Florestais com Interesse Para Portugal: Zonas de Influência Atlântica; Direcção-Geral das Florestas: Lisboa, Portugal, 2003; p. 322.

33. WebGlobulus. Available online: http://home.isa.utl.pt/ \{\}joaopalma/modelos/webglobulus/ (accessed on 21 September 2020).

34. Tomé, M.; Ribeiro, F.; Soares, P. O Modelo Globulus 2.1. Relatórios Técnico-Científicos do GIMREF, no. 1/2001; Departamento Engenharia Florestal, ISA: Lisbon, Portugal, 2001; p. 69.

35. Tomé, M.; Oliveira, T.; Soares, P. O Modelo Globulus 3.0. Publicações GIMREF-RC2/2006; Universidade Técnica de Lisboa, Instituto Superior de Agronomia, Centro de Estudos Florestais: Lisbon, Portugal, 2006; p. 23.

36. Röser, D.; Asikainen, A.; Stupak, I.; Pasanen, K. Forest energy resources and potentials. In Sustainable Use of Forest Biomass for Energy: A Synthesis with Focus on the Baltic and Nordic Region. Managing Forest Ecosystems; Röser, D., Asikainen, A., RaulundRasmussen, K., Stupak, I., Eds.; Springer: Dordrecht, The Netherlands, 2008; Volume 12, pp. 9-28. [CrossRef]

37. Smith, W.B.; Miles, P.D.; Perry, C.H.; Pugh, S.A. Forest Resources of the United States, 2007; U.S. Department of Agriculture, Forest Service: Washington, DC, USA, 2009; p. 336.

38. R Core Team. R: A Language and Environment for Statistical Computing; R Foundation for Statistical Computing: Vienna, Austria, 2020.

39. Demirbaş, A. Calculation of higher heating values of biomass fuels. Fuel 1997, 76, 431-434. [CrossRef]

40. Jenkins, B.M.; Baxter, L.L.; Miles, T.R. Combustion properties of biomass. Fuel Process. Technol. 1998, 54, 17-46. [CrossRef]

41. Quaak, P.; Knoef, H.; Stassen, H. Energy from Biomass: A Review of Combustion and Gasification Technologies; The World Bank: Washington, DC, USA, 1999; p. 78. [CrossRef]

42. Strezov, V. Properties of biomass fuels. In Biomass Processing Technologies; Strezov, V., Evans, T.J., Eds.; CRC Press: Boca Raton, FL, USA, 2014; pp. 1-32.

43. Vassilev, S.V.; Vassileva, C.G.; Vassilev, V.S. Advantages and disadvantages of composition and properties of biomass in comparison with coal: An overview. Fuel 2015, 158, 330-350. [CrossRef]

44. Arteaga-Pérez, L.E.; Segura, C.; Bustamante-García, V.; Cápiro, O.G.; Jiménez, R. Torrefaction of wood and bark from Eucalyptus globulus and Eucalyptus nitens: Focus on volatile evolution vs. feasible temperatures. Energy 2015, 93, 1731-1741. [CrossRef]

45. Phyllis2, Database for Biomass and Waste. Available online: https://www.ecn.nl/phyllis2 (accessed on 24 April 2021).

46. Miranda, I.; Almeida, M.; Pereira, H. Provenance and site variation of wood density in Eucalyptus globulus Labill. at harvest age and its relation to a non-destructive early assessment. For. Ecol. Manag. 2001, 149, 235-240. [CrossRef]

47. Gominho, J.; Lourenço, A.; Miranda, I.; Pereira, H. Chemical and fuel properties of stumps biomass from Eucalyptus globulus plantations. Ind. Crop. Prod. 2012, 39, 12-16. [CrossRef]

48. Vicente, E.; Tarelho, L.; Teixeira, E.; Duarte, M.; Nunes, T.; Colombi, C.; Gianelle, V.; Da Rocha, G.; De La Campa, A.S.; Alves, C. Emissions from the combustion of eucalypt and pine chips in a fluidized bed reactor. J. Environ. Sci. 2016, 42, 246-258. [CrossRef]

49. Gonçalves, A.C.; Malico, I.; Sousa, A.M.O. Energy production from forest biomass: An overview. In Forest Biomass-From Trees to Energy; Gonçalves, A.C., Sousa, A., Malico, I., Eds.; IntechOpen: London, UK, 2021; pp. 1-23. [CrossRef]

50. Altri. Available online: http:/ / www.altri.pt/en (accessed on 19 February 2019).

51. Patrão, G. The Portuguese Energy Strategy and the role of Biomass. Workshop BIOGAIR: Biomass on the Portuguese Energy Sector; Universidade de Aveiro: Aveiro, Portugal, 13 May 2011.

52. Silva, J.P.; Teixeira, J.; Teixeira, S.; Preziati, S.; Cassiano, J. CFD Modeling of Combustion in Biomass Furnace. Energy Procedia 2017, 120, 665-672. [CrossRef]

53. David, J.S.; David, T.S.; Valente, F. O eucaliptal e os recursos hídricos. In O Eucaliptal em Portugal; Alves, A.M., Pereira, J.S., Silva, J.M.N., Eds.; ISAPress: Lisbon, Portugal, 2007; pp. 113-135.

54. Persson, T.; Egnell, G. Stump harvesting for bioenergy: A review of climatic and environmental impacts in northern Europe and America. Wiley Interdiscip. Rev. Energy Environ. 2018, 7, e307. [CrossRef]

55. Madeira, A.C.; Madeira, M.; Fabião, A.; Marques, P.; Carneiro, M. Impact of harvest residues, fertilisers and N-fixing plants on growth and nutritional status of young Eucalyptus globulus plantations, under Mediterranean conditions. Eur. J. For. Res. 2010, 129, 591-601. [CrossRef]

56. Carneiro, M.; Fabião, A.; Martins, M.C.; Cerveira, C.; Santos, C.; Nogueira, C.; Lousa, M.; Hilario, L.; Fabião, A.; Abrantes, M.; et al. Species richness and biomass of understory vegetation in a Eucalyptus globulus Labill. coppice as affected by slash management. Eur. J. For. Res. 2006, 126, 475-480. [CrossRef] 